\title{
Foreign Missions' Role in Promoting International Trade: Empirical Evidence of Sri Lankan Foreign Missions Promoting Electronic Exports in Germany
}

\author{
R. T. Vidyaratne ${ }^{1} \&$ E.A.G. Sumanasiri ${ }^{2}$ \\ ${ }^{1}$ Master of Business Administration, Faculty of Management Studies and Commerce, University of Sri \\ Jayewardenepura, Sri Lanka \\ ${ }^{2}$ Department of Commerce, Faculty of Management Studies and Commerce, University of Sri Jayewardenepura, \\ Sri Lanka \\ Correspondence: R. T. Vidyaratne, Faculty of Management Studies and Commerce, University of Sri \\ Jayewardenepura, Sri Lanka.
}

Received: May 20, 2020

doi:10.5539/ibr.v13n7p173
Accepted: June 17, 2020

Online Published: June 23, 2020

URL: https://doi.org/10.5539/ibr.v13n7p173

\begin{abstract}
Foreign missions have been the pillars of trade promotion and in particular, of export and export-oriented investment. In Sri Lanka, the potentiality in export promotion to Germany is immense. However, it is discernible that there is no coordinated effort in promoting trade in Sri Lanka by foreign missions. Therefore, this research examines the role of foreign missions in promoting international trade between Sri Lanka and Germany especially focusing on Electrical and Electronic Sector. The case study is based on the empirical evidence of Sri Lankan foreign missions promoting electrical and electronic exports in Germany. Potential growth-enhancing factors will benefit from increased global economic integration through trade promotion activities undertaken by the host country and the foreign mission. A qualitative methodology was used to understand the stakeholder perspective of the role of foreign missions. Analysis of data collected through semi-structured interviews (13) derived the results that trade fairs and Business to Business meetings as the most effective trade promotion activities. Findings of the study confirms six (6) vital roles of a foreign mission which are internalizing industries, promoting, business intelligence, stakeholder communication, building strategic relationships and inter-governmental engagement respectively. The paper points out managerial and policy implications such as pro-activeness of the head of foreign missions and strategic and trustworthy relationships between the countries. The study concludes that the activities carried out by the Sri Lankan Foreign Mission in Germany does not satisfy the exporters' expectations and requirements. Further this study recommendations are provided to both German and Sri Lankan Governments and foreign missions.
\end{abstract}

Keywords: business-government relations, commercial diplomacy, economic diplomacy, export and investment promotion, internationalisation of business

\section{Introduction}

Although the world economy was recovering in 2017, notwithstanding ups and downs (Diplomatic Bluebook, 2018), in terms of Gross Domestic Product (GDP) growth, Asia is continuing to grow rapidly, and it is expected to do much better than other regions in the near (Ministry of Foreign Affairs \& Bandaranaike International Diplomatic Training Institute, 2019/2019). With this rapid pace of global economic growth, Sri Lanka as an emerging economy should focus more on its supply chain and promotional aspects of their products and services in order to compete with other countries (Ministry of Foreign Affairs \& Bandaranaike International Diplomatic Training Institute, 2019).

Foreign Missions (FMs) have been the pillars of promoting trade and specifically in relation to exports and export-oriented investments (Rose, 2005). FMs popularly act as information sources, albeit with many other ways of obtaining information in this era such as the Internet and other data sources (Rose, 2005). FMs also play a major role in attracting buyers and creating linkages (Rose, 2005). 


\subsection{Background of the Study}

At present Sri Lanka maintains 52 High Commissions/Embassies overseas (MFA 2019). The most important activities carried out through a foreign mission in general are:1. Business Intelligence, 2. Assistance with fairs, trade missions and networking, 3. Problem solving and assistance with trade disputes, and 4. Business partner search and negotiation (Kostecki and Naray, 2007).

In Sri Lanka, the Electrical and Electronic (EE) sector is one of the emerging sectors supported by the National Export Strategy (NES) and currently the sector serves niche markets that have great potential to diversify their markets (Electrical and Electronic Components, 2018). The EE sector is also considered to have potential to stimulate innovation, research and development $(\mathrm{R} \& \mathrm{D})$ and investment in the country (Electrical and Electronic Components, 2018).

Sri Lanka is considered as a country with a strong leadership in its foreign policy based on the principle of non-alignment which balances the interests and influence of powerful neighbouringcountries. Sri Lanka's relations with the Federal Republic of Germany were established on 9 December 1953 (Germany | Ministry of Foreign Affairs Sri Lanka, 2017).

Sri Lanka's engagement with regional and international fora, including the United Nations, the European Union, SAARC, BIMSTEC and ARF has demonstrated the transparent and constructive engagement of the Government through its foreign relations at all levels (Ministry of Foreign Affairs Sri Lanka, 2019). The Mission of the Ministry of Foreign Affairs (MFA) is defined as to promote, project and protect Sri Lanka's national interests overseas, in consonance with the foreign policy of the Government of Sri Lanka. In 2018 MFA, has continued to enhance Sri Lanka's engagement in the political, economic, social and cultural spheres, strengthening the concept of 'Friendship with all, and enmity towards none' (Ministry of Foreign Affairs Sri Lanka, 2019).

\subsection{Research Problem}

Certain challenges highlighted in the literature when promoting EEC as a major export of Sri Lanka are:

Firstly, uncertainty arising from information asymmetry is identified as one of the major trade barriers especially for new destinations mostly in developing countries.

Secondly, barriers of language, bureaucratic procedures and all the security concerns that contribute to the sunk cost a firm has to take into account when entering a new market (Bagir, 2017). However, in this process of promoting exports in the EEC sector in the international market the foreign missions are recognized as the responsible stakeholder through their diverse networks.

\subsection{Research Objectives}

This study aims:

\section{'To explore the role of the foreign mission in promoting exports in the host market' and}

'To identify the effective international trade promotional activities organized by the foreign mission in the host market'

\subsection{Research Questions}

The following questions aim to explore the project objectives of this study.

1. What are the roles of the Sri Lankan foreign missions (Embassy and Consulate) in Germany in promoting international trade in the host market?

2. What are the most successful international trade promotional activities organized by the Sri Lankan foreign mission in Germany?

3. What are the most effective trade promotion activities that should be carried out by foreign missions?

\section{Literature Review}

\subsection{Developing Conceptual Framework}

The literature on the subject states that the role of foreign missions in promoting trade between countries is unclear. Many commonly ask whether the activities carried out by foreign missions are actually client requirements. Therefore, foreign missions should identify and understand the requirements of stakeholders prior to carrying out their activities. 


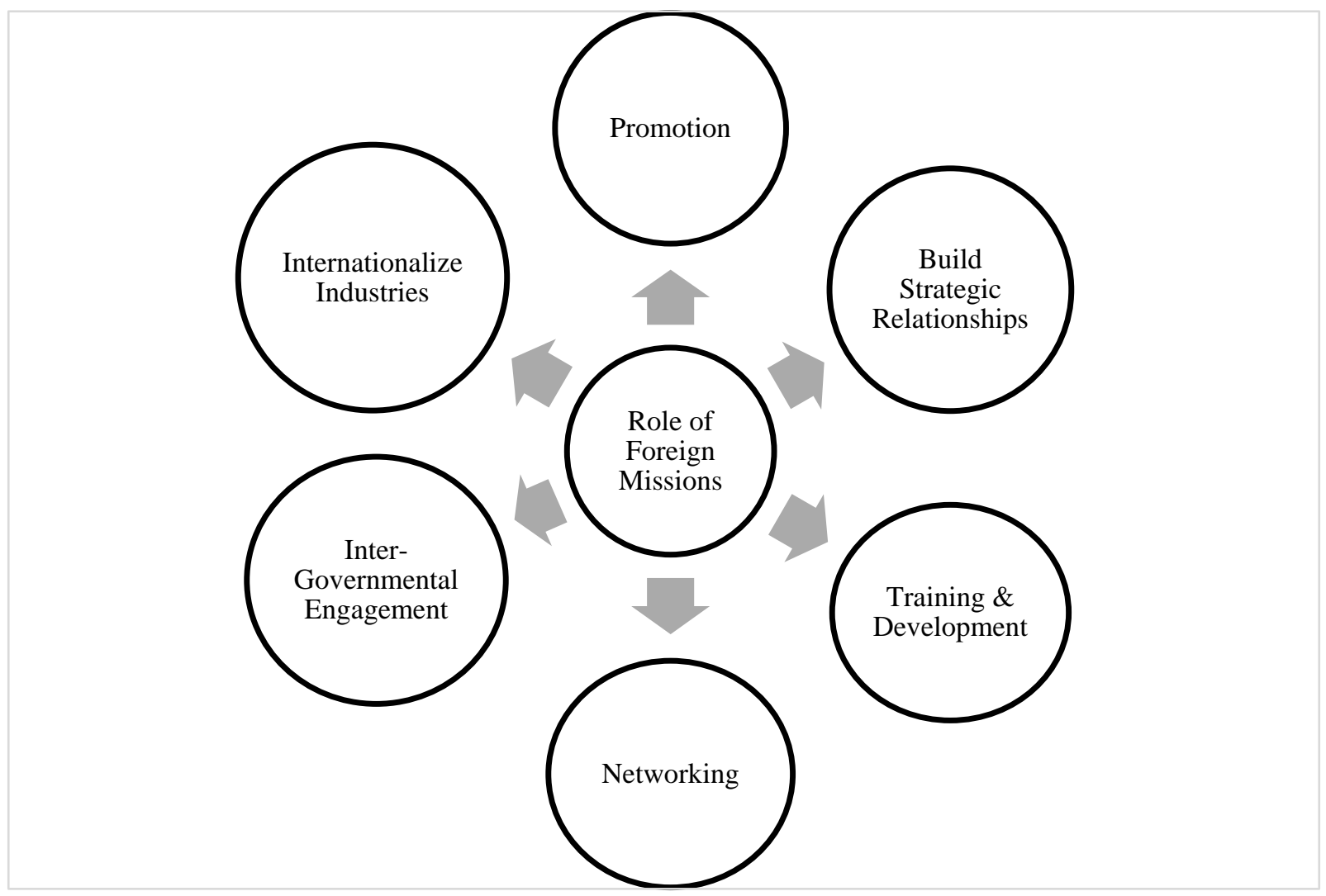

Figure 1. Different Aspects of Role of the Foreign Mission

Source: (Naray, 2015)

\subsection{Commercial Diplomacy}

Commercial diplomacy (CD) helps governments to improve their international trade and enhance national economic stability. The term CD is commonly used to describe the business support functions performed by diplomatic missions, their staff and related agencies (Naray, 2015). CD is a means for governments to increase international trade and support their national economies (Ruel \& L. Zuidema, 2012) As developing countries are most likely to remain a reality, and work as the engines of economic growth in the advancing centuries, advanced government economies need to reinforce the tools they use such as commercial diplomacy, while also at same time deal with budget reductions in the country (Ruel \& L. Zuidema, 2012).

Many researchers recognize other types of diplomacy that follow an economic objective. Okano-Heijmans (2011) mentioned $\mathrm{CD}$, trade diplomacy, financial diplomacy, incentives and sanctions as strands of economic diplomacy. From this perspective CD would be part of economic diplomacy (Ruel \& L. Zuidema, 2012). Economic diplomacy is concerned with general economic policy issues and trade agreements albeit with both having an overarching economic objective. CD is much more specific. Mercier (2007) and Kostecki and Naray (2007) both highlighted that $\mathrm{CD}$ is often used to deal with two different types of activities: policy-making and business support (Ruël et al., 2012).

While many agree that the core of commercial diplomacy focuses on specific business support, many of the definitions of various authors differ (Ruël et al., 2012).

\subsubsection{Defining Commercial Diplomacy}

CD centers around a series of activities in order to promote and facilitate international business. Potter, (2004) for instance, defines $\mathrm{CD}$ as; "the application of tools of diplomacy to help bring out specific commercial gains through promoting exports, attracting inward investment, and preserving outward investment opportunities, and encouraging the benefits of technological transfer" (Ruël et al., 2012).

Lee (2004) defines it as "the work of a network of public and private actors who manage commercial relations 
using diplomatic channels and processes" (Ruël et al., 2012). This definition suggests that both private and public actors conduct CD. Saner and Yiu (2003) consider CD conducted by private actors as corporate or business diplomacy (Ruël et al., 2012).

Thus, private actors should preferably be excluded from the definition of CD. Finally, Naray (2007) defines it as "an activity conducted by public actors with diplomatic status in view of business promotion between a home country and a host country. It aims at encouraging business development through a series of business promotion and facilitation activities" where these activities are performed by members of foreign diplomatic missions, their staff, and other related agencies (Ruël et al., 2012).

According to Naray (2007), the following are the activities related to CD (Ruël et al., 2012). They are related to specific areas such as markets and goods or intellectual property rights.
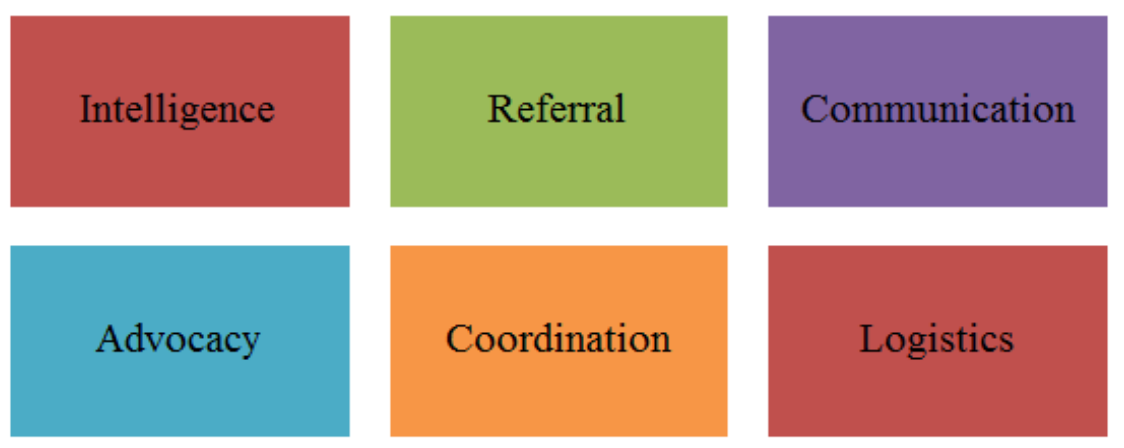

Figure 2. Naray's (2015) Commercial Diplomacy Activity Classification

Source: An Empirical Analysis of the Roles, Activities and Performance of Commercial Diplomats in Promoting International Business (Naray, 2015)

\subsubsection{Themes of Commercial Diplomacy}

CD often covers two different types of activities: First activities relating to trade policy-making (for example, multilateral trade negotiations, trade consultations and dispute settlement) and second business-support activities (Sorenson \& Curzon, 1966; Saner and Yiu, 2003).

Table 1. Themes of Commercial Diplomacy

\begin{tabular}{|l|l|}
\hline \multicolumn{1}{|c|}{$\begin{array}{c}\text { Major theme explaining the } \\
\text { role of FM }\end{array}$} & \multicolumn{1}{c|}{ Explanation } \\
\hline $\begin{array}{l}\text { CD in government's } \\
\text { export/trade promotion } \\
\text { function } \\
\text { (Naray, 2015) }\end{array}$ & $\begin{array}{l}\text { Government's role and actions generally in its trade/export promotion function (in } \\
\text { the generic sense). In the macro level approach, CD is considered either (i) in a } \\
\text { broad sense and encompassing government's trade promotion initiatives or (ii) as a } \\
\text { "programme" or one initiative among others to promote trade. }\end{array}$ \\
\hline $\begin{array}{l}\text { CD's institutional } \\
\text { /organisational arrangements } \\
\text { (Naray, 2015) }\end{array}$ & $\begin{array}{l}\text { Institutional and organisational arrangements, which often stem from a country's } \\
\text { institutional traditions, culture and current trends in public-sector reform. The CD's } \\
\text { unit position is at the centre of organizational concerns. Governments play a major } \\
\text { part, yet the private sector and semi-public entities are also involved in commercial } \\
\text { diplomatic activities. Various partners and stakeholders are involved beyond the } \\
\text { government ministry. }\end{array}$ \\
\hline $\begin{array}{l}\text { Commercial diplomat's } \\
\text { managerial roles (Naray, } \\
\text { 2015) }\end{array}$ & $\begin{array}{l}\text { Roles are typically carried out by CDs; and their weight and aspects are thus often } \\
\text { different from these of other business support organizations. }\end{array}$ \\
\hline $\begin{array}{l}\text { Interaction between the } \\
\text { commercial diplomat and } \\
\text { business enterprises } \\
\text { (Naray, 2015) }\end{array}$ & $\begin{array}{l}\text { Many firms are discouraged from exporting due to high import barriers. Small and } \\
\text { Medium Enterprises (SMEs) and large enterprises alike have an interest in } \\
\text { interacting with CDs to obtain advice and support in the internationalization process. }\end{array}$ \\
\hline
\end{tabular}

Source: (Naray, 2015) 


\subsubsection{Activities Performed by a Foreign Mission}

Table 1. Activities based on the researchers

\begin{tabular}{|l|l|}
\hline Researcher & Activities \\
\hline Naray (2008) & Intelligence, referral, communication, advocacy, coordination, and logistics \\
\hline $\begin{array}{l}\text { Lederman, Olarreaga and } \\
\text { Payton (2006) }\end{array}$ & $\begin{array}{l}\text { Country image building, export support services, marketing, and market research and } \\
\text { publications }\end{array}$ \\
\hline Kostecki and Naray (2004) & $\begin{array}{l}\text { Support activities and primary activities. support activities including intelligence, networking } \\
\text { and public relations, contract negotiations, and problem solving, providing inputs for primary } \\
\text { activities: trade promotion, promotion of FDI, Science and Technology cooperation, promotion } \\
\text { of tourism, and national business community advocacy }\end{array}$ \\
\hline Kotabe and Czinkota (1992) & Export service programs (counseling and advice) and market development programs \\
\hline Lee (2004) & $\begin{array}{l}\text { Gathering and dissemination of market information, development and introduction of } \\
\text { government relations and promotion of home country products and services by means of trade } \\
\text { fairs, lobbying, and organizing seminars }\end{array}$ \\
\hline
\end{tabular}

Source: (Ruël et al., 2012)

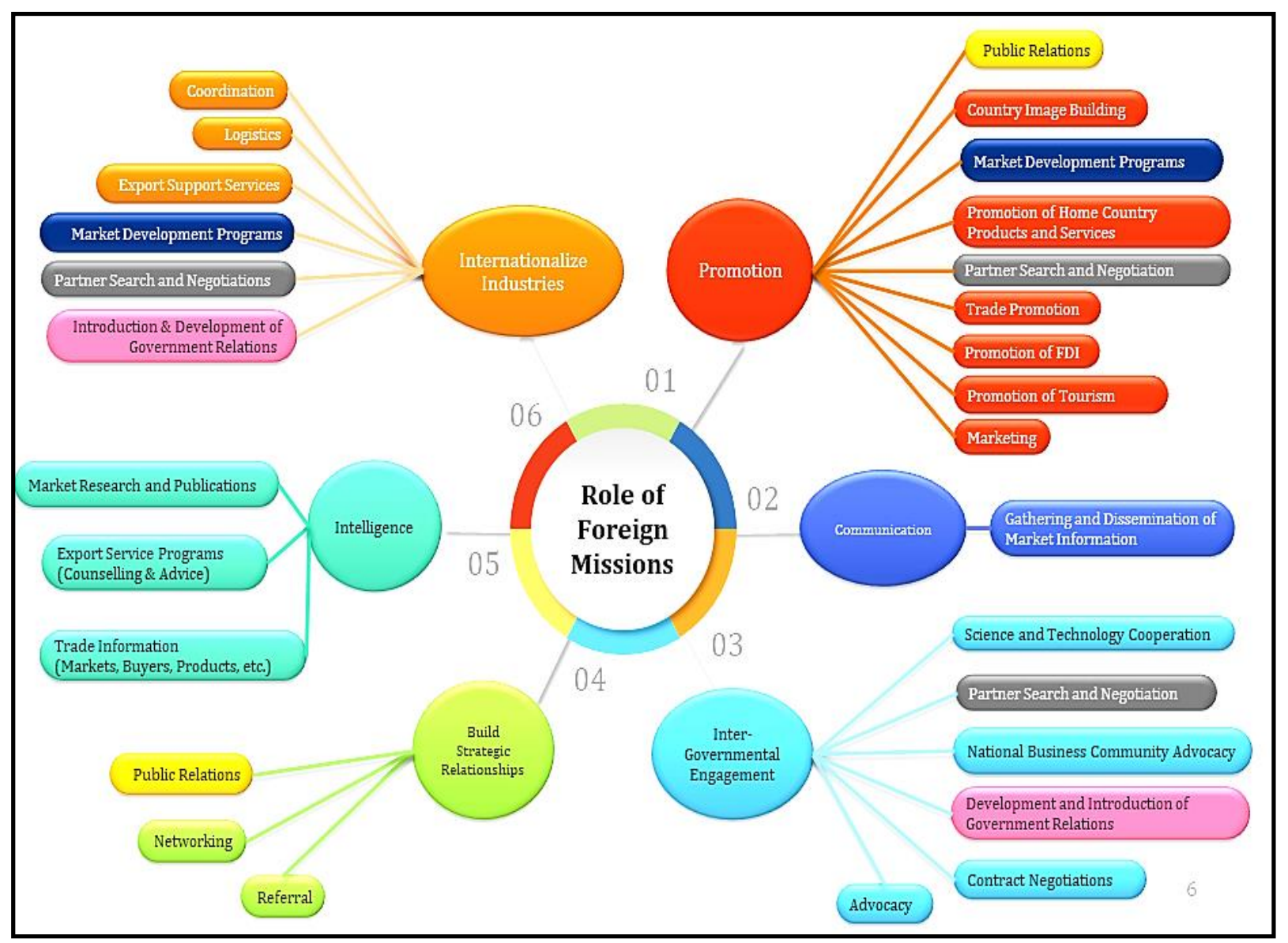

Figure 2. Different Aspects of the Role of a Foreign Mission

\subsubsection{Conceptual Framework}

Based on the above empirical studies, this study develops a conceptual framework Figure 3. It identifies six (6) major roles of a foreign mission in general as reflected in the Figure 3.

\subsection{Sri Lanka's Foreign Policy in a Nutshell}

Following are the objectives of Sri Lanka's foreign policy (Ministry of Foreign Affairs Sri Lanka, 2019) 


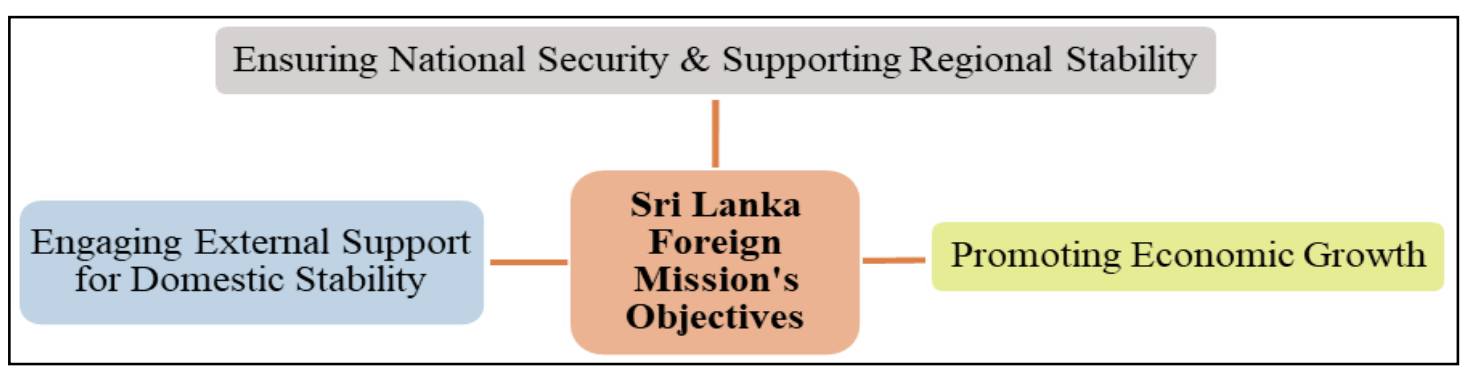

Figure 4. Objectives of Sri Lanka's Foreign Policy

Source: Developed by the Researcher using available literature

As per the foreign policy of Sri Lanka, the role of foreign missions can be depicted as follows (Ministry of Foreign Affairs Sri Lanka, 2019).

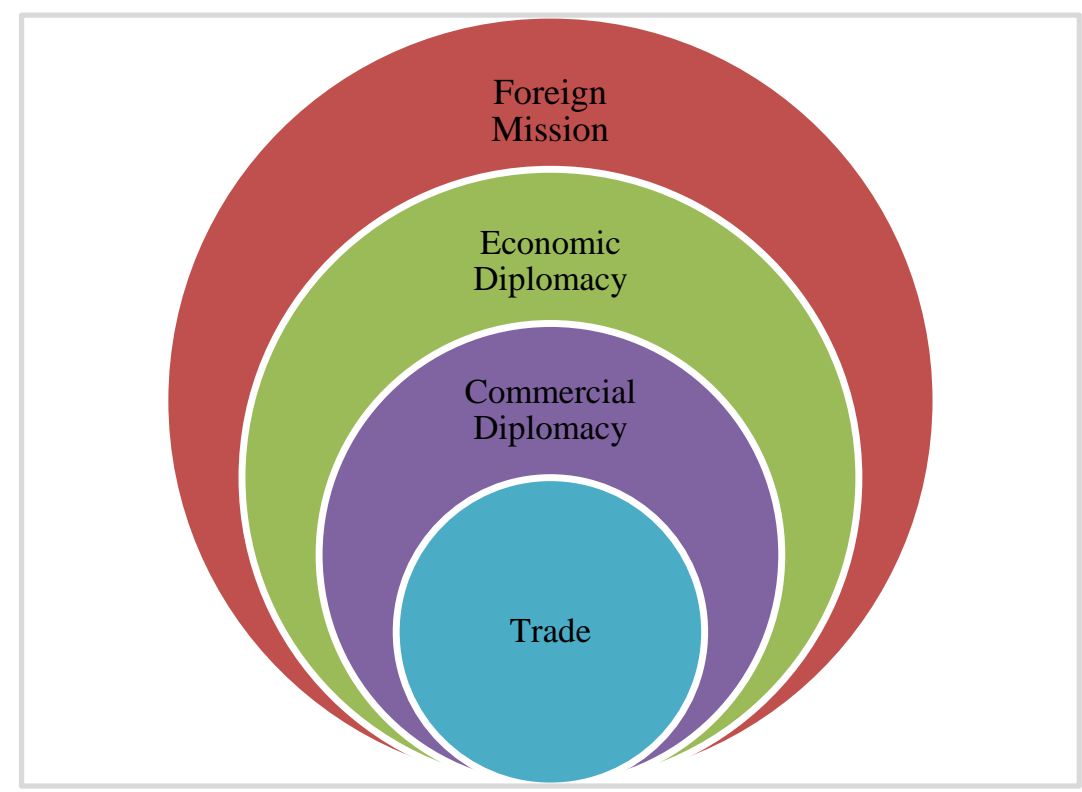

Figure 3. Flow of Foreign Missions

Source: Developed by the Researcher using available literature (Palangkaraya and Webster, 2019), (Okano-Heijmans 2011)

\subsection{Electrical and Electronic (EE) Sector}

The EE sector has risen globally from 1.75 trillion dollars in 2008 to 2.1 trillion dollars by 2015, and is projected to increase to 2.4 trillion dollars by 2020 (Electrical and Electronic Components, 2018). The industry encompassing consumer appliances, information and communication technology, industrial electronics, aerospace, and defense has seen on-going growth over the past two decades, driven by both demand and industrial infrastructure. Despite the massive worldwide development in the electronics industry, there has been limited involvement in the sector in Sri Lanka so far.

Electrical and Electronic Components, 2018, highlighted that the Government of Sri Lanka is required to concentrate on the EE industry and play a proactive role by undertaking the following actions:

1. Providing early assistance to the EE sector through the introduction of a domestic industry development structure with targeted product lines and promoting investment in these product lines.

2. Initiating numerous initiatives of domestic significance that will contribute to the improvement of the EEC industry. 
3. Stimulating domestic demand for electronics products. For example, the government could encourage rooftop solar or light emitting diode (LED) lighting so that these products could be manufactured in large quantities for domestic consumption and export.

\subsection{Germany Country Profile}

Germany is the second largest export economy in the world and the third most complex economy according to the Economic Complexity Index (ECI). In 2017, Germany exported \$1.33T and imported \$1.08T, resulting in a positive trade balance of $\$ 251 \mathrm{~B}$. In 2017 the GDP of Germany was $\$ 3.68 \mathrm{~T}$ and its GDP per capita was $\$ 50.6 \mathrm{k}$ (OEC.world, 2019).

According to the Observatory of Economic Complexity (OEC) tool, the top exports of Germany are Cars (\$158B), Vehicle Parts (\$64.1B), Packaged Medicaments (\$50.6B), Planes, Helicopters, and/or Spacecraft (\$27.2B) and Human or Animal Blood (\$23.7B), using the 1992 revision of the HS (Harmonized System) classification. Its top imports are Cars $(\$ 60 \mathrm{~B})$, Vehicle Parts $(\$ 42.1 \mathrm{~B})$, Crude Petroleum $(\$ 30.1 \mathrm{~B})$, Packaged Medicaments (\$25.8B) and Human or Animal Blood (\$22.1B) (OEC.world, 2019).

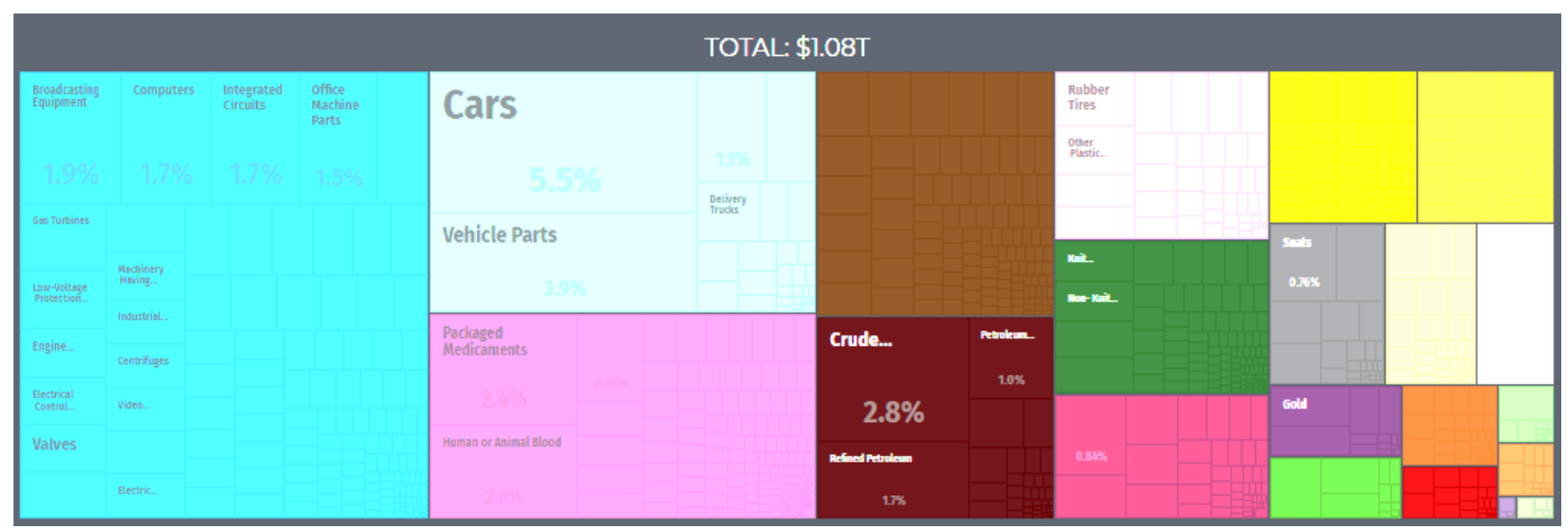

Figure 4. Imports of Germany

Source: (OEC.world, 2017).

The automotive industry is the backbone of the German industry and has become increasingly important. It contributes significantly to German GDP and employment. The sector continuously increased its share of total value added from 3.1 percent in 1995 to 5.3 percent in 2016, well above the EU average of 2.3 percent in 2016 (with France, Spain and Italy at 1.5 percent, 1.7 percent and 1.4 percent respectively) (European Commission, 2019). Handheld Electronic Books, Batteries and Solar Cells-all of which can be printed as paper-are just some of the technological innovations presently being created in Germany. Automotive Electronics is the largest segment of the German electronics industry with a market share of 42 percent. Industrial Electronics accounts for almost 25 percent of the sales of German electronics.

\subsection{Sri Lanka's International Trade with Germany}

Trade statistics between Sri Lanka and Germany in the past decade is depicted below in Figure 1. It shows a growth of exports to Germany in the past decade (ITC Export Potential Map, 2019).

Further, according to a study of Kotabe and Czinkota (1992), export promotion activities include export service programs and market development programs (Broek, 2019).

\section{Methodology}

This study follows a qualitative methodology. The extant literature shows that many quantitative studies have been carried out in this range of work (Ruël et al., 2012). However, these studies failed to explain the role of a foreign mission in succeeding in the international market. To achieve this objective a qualitative methodology would permit researchers to understand human behavior and thoughts on understanding the preferences in trade promotion activities. Hence the qualitative method was selected.

\subsection{Data Collection Method and Sample}

In order to examine the roles of the foreign mission and the success of its trade promotional activities data was collected through two main sources, namely, structured interviews and focus group discussions while secondary 
sources such as international trade databases and trade maps were used to triangulate the data. In total, 14 semi-structured interviews were conducted using the convenient sampling method. Population includes Sri Lankan exporters and importers, trade support institutions and diplomats. Number of respondents in the population is infinite and respondents are scattered across two geographical locations. Therefore, this sampling method is used for this study. Interviewees consisted of diverse stakeholders and knowledgeable informants so as to improve the quality of the findings. To expand further, Snowball sampling was used to collect data owing to time limitations and convenience.

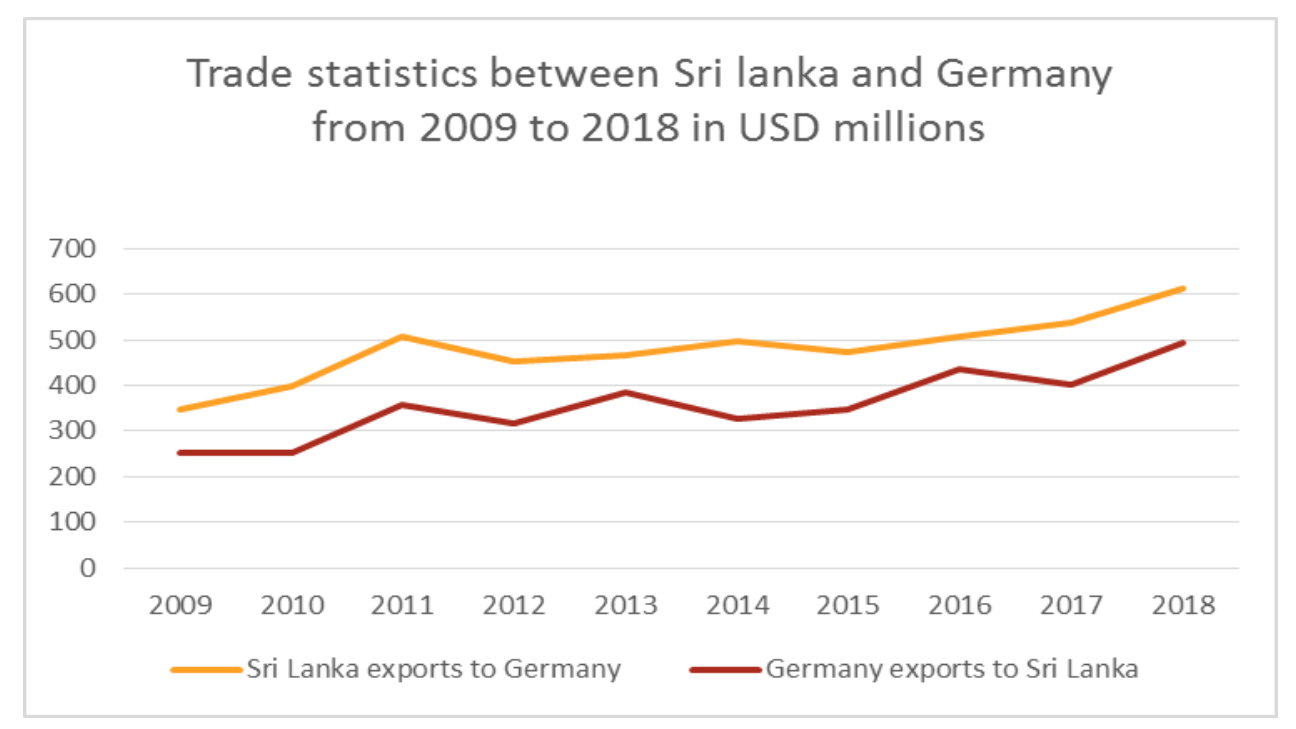

Figure 5. Trade Statistics between Sri Lanka and Germany

Source: EDB, CBSL

Table 3. Respondent Profile

\begin{tabular}{|c|c|c|c|c|}
\hline Interviewee & Stakeholder Type & Job Rank & Sector & Nationality \\
\hline INT 1 & $\begin{array}{l}\text { Officials from Sri Lankan Embassy } \\
\text { in Germany }\end{array}$ & Senior Management & $\begin{array}{l}\text { Consulate } \\
\text { General of Sri } \\
\text { Lanka }\end{array}$ & Sri Lankan \\
\hline INT 2 & \multirow{2}{*}{$\begin{array}{l}\text { Delegation of German Industry and } \\
\text { Commerce in Sri Lanka (AHK) }\end{array}$} & Senior Management & AHK & Sri Lankan \\
\hline INT 3 & & Middle Management & AHK & Sri Lankan \\
\hline INT 4 & \multirow[t]{2}{*}{ Sri Lankan Exporters of EEC Sector } & Senior Management & $\begin{array}{l}\text { HiTech } \\
\text { Solutions }\end{array}$ & Sri Lankan \\
\hline INT 5 & & Senior Management & GPV Lanka & Sri Lankan \\
\hline INT 6 & $\begin{array}{l}\text { Selected German Importers of the } \\
\text { EEC sector }\end{array}$ & Senior Management & $\begin{array}{l}\text { HiTech } \\
\text { Solutions } \\
\end{array}$ & Sri Lankan \\
\hline INT 7 & \multirow{3}{*}{$\begin{array}{l}\text { Officials from the Export } \\
\text { Development Board }\end{array}$} & Middle Management & EDB & Sri Lankan \\
\hline INT 8 & & Junior Management & EDB & Sri Lankan \\
\hline INT 9 & & Junior Management & EDB & Sri Lankan \\
\hline INT 10 & $\begin{array}{l}\text { Officials from the International } \\
\text { Trade Centre }\end{array}$ & Senior Management & $\begin{array}{l}\text { International } \\
\text { Trade Centre } \\
\text { Geneva Office }\end{array}$ & Canadian \\
\hline INT 11 & \multirow{2}{*}{$\begin{array}{l}\text { Sri Lanka Electronic } \\
\text { and } \text { Manufacturers } \\
\text { (SLEMEA) members }\end{array}$} & Senior Management & Synopsis & Sri Lankan \\
\hline INT 12 & & Senior Management & Zone 24 x 7 & Sri Lankan \\
\hline
\end{tabular}

A semi-structured interview protocol was developed based on an extensive literature review. Prior to conducting the interviews, this protocol was tested for its content by two experts in the EEC sector and one senior executive from the EDB in the field of international trade promotion activities. Each interview took approximately 20-30 minutes in general. Two interviews were carried out as a focus group discussion. Out of 12 interviews, 10 were individual interviews and were conducted either through Skype (1), telephone conversations (1), email (3) and face-to-face conversations (3). The interviews were recorded with the permission of the interviewee while notes were taken by the researcher during the interviews. Confidentiality and anonymity were ensured throughout in 
respect of the interviewees.

The collected interview data was first recorded and then transcribed in English (Aberdeen, 2013). A word processing technique was used to carry out the analysis. Themes and sub-themes were identified to understand the role and the success of the foreign missions in promoting international trade.

Secondary data was collected from the Export Development Board (EDB), Central Bank of Sri Lanka (CBSL), Sri Lanka Customs, European Union (EU), International Trade Centre (ITC) and the World Trade Organization (WTO) and analyzed through the content analysis method. Quantitative figures from these secondary data sources were mostly used to triangulate the qualitative data gathered through the interviews.

\section{Results}

4.1 Findings for the Research Question (RQ) 1: What Are the Roles of the Sri Lankan Foreign Missions in Germany in Promoting International Trade?

This question aimed to identify diverse perceptions of stakeholders about the roles of Sri Lankan foreign mission in promoting international trade in Germany. Accordingly, questions were developed in the semi-structured interview protocol to identify the role of the Foreign Missions (FM) in Germany to promote international trade.

INT 01 stated that the activities of the embassy and the consulate are handling trade inquiries, trade fairs, investment promotion, tourism promotion, providing information, market intelligence and arranging business-to-business meetings on request. INT 1 specifically mentioned that the trade promotion activities are carried out by the Consulate General in Frankfurt while political and tourism promotion is carried out by the Sri Lankan Embassy in Berlin.

There are 2 missions in Germany. The Ambassador is in Berlin and the political and administration activities are done in Berlin. As a commercial officer, we are in Frankfurt. We mainly look after the trade promotional activities"

\section{- $\quad$ INT 1 - Consulate General in Frankfurt}

According to INT 1 and the Annual Performance Report of the Ministry of Foreign Affairs Sri Lanka (2018, 2019) trade promotion activities undertaken by the Embassy of Sri Lanka in Germany relating to the EEC sector are as follows:

1. A delegation from German Industry and Commerce in Sri Lanka helped to expedite bilateral trade and investment.

2. The Minister of Development Strategies and International Trade participated in the Business Forums organized in collaboration with the Delegation of German Chambers and Industry and the Board of Investment of Sri Lanka.

INT 6 reveals what a Sri Lankan Exporter from the EEC Sector expected from the German Embassy. He also stated that they expected the embassy to promote Sri Lankan companies as an outsourcing destination for research and development $(\mathrm{R} \& \mathrm{D})$. The interviewee also mentioned that one reason for effective communication can be the language barrier in promoting in Germany. Furthermore, investment criteria of interest should be identified. In addition, timeliness and quality are major features of the German market. INT 6 especially mentioned about the support they require from the foreign mission in identifying opportunities in the German market and introducing them and disseminating information on the available opportunities. INT 6 further elaborated on his expectations from the foreign missions such as creating a product service map. He explained it as researching, identifying and understanding the products which should be produced in Sri Lanka so that the supply chain can focus on those needs and support and plug into that particular value chain.

INT 3 and INT 4 are officials from the Delegation of German Industry and Commerce in Sri Lanka (AHK). They stated that the role of foreign missions is to understand the requirement of the host country and they should plan their promotions accordingly.

"....my plans for the next five years include another trade fair. I want to target it and then I will cut it down. I will narrow it down for the mid-term. I think the EDB or the entity has to have a long-term plan. These are the sectors that we want to cover. And these are the trade fairs that we want to target and what are the major trade fairs to promote these sectors...."

- $\quad$ INT 3 - AHK

INT 6 is an Exporter of the EEC sector and he mentioned that by forming partnerships with allied organizations it will be possible to better expose Sri Lanka's capabilities to high growth markets that are still unaware of the 
country's capabilities.

".... expecting from the German embassy. What are the likely gaps they have? So, we can fill them. The investment they like to do....."

- $\quad$ INT 6 - Sri Lankan Exporter

INT 7, an Exporter of the EEC sector, mentioned that the FM should help companies to gain a better understanding of market specific knowledge and knowledge on international business processes.

INT 8, an Importer of the EEC sector, stated that necessary information and guidance for enterprises should be provided in understanding and accessing international markets.

INT 11 stated that neither the Embassy nor the Consulate had taken the initiative to support the EEC sector. He further stated that generally, the embassy in Germany and the Consulate in Germany carry out trade promotion activities in Sri Lanka in respect of tea, rubber, coconut, apparel and other sectors.

“....But specifically if we take, say, the electronic sector, they have not been doing the expected promotional activities up to now, but we are trying our level best to get the support....."

INT $11-E D B$

INT 12 was on a training carried out by the Import Promotion Desk (IPD), Germany. IPD is an initiative for import promotion in Germany, active in 13 countries and five sectors. It is the pivot between small and medium-sized enterprises in selected developing and emerging countries and European importers. The Import Promotion Desk intensifies activities for sustainable economic development. Hence, exposure to German trade fairs was obtained through this programme. Visiting and experiencing an electronic and machinery technology-related trade fair was one of the activities and the interviewee gathered information on pre-fair workshops and further elaborated on the selection of trade fairs to participate in and the importance of the selection.

The interviewee was also on a training programme carried out by the IPD. The training included participation in the Anuga Fair, the world's largest trade fair for food and beverages.

Both of the Interviewees emphasized the importance of a National Pavilion at a trade fair. The following was mentioned as the value addition from a National Pavilion.

1. Functional values - Country branding, Market linkage, Match making, Promotional material, Access to special exhibitions, Location advantage, Preparation meetings, Parallel event participation.

2. Commercial values - For SMEs-Guidance, for Large Companies-Recommendations

They further mentioned that training programmes for EDB officers and an action plan for SME support activities at trade fairs were crucial. They also stated that IPD was willing to train EDB officers to develop their capacity with a view to supporting and developing the SME sector to promote the German market. Further, trade fair participation activities with real time schedule (Washing Line) should be introduced. Moreover, conducting a preparatory workshop for exhibitors (SMEs) and a post-participation workshop for evaluation is another aspect mentioned in their statements.

INT 14 is from the International Trade Centre (ITC). He defined the role of foreign missions in promoting international trade in a host market as follows:

“... I would think the role of the mission is to be aware of the SL products to be promoted based on the market development orientation provided by EDB and the Ministry of Foreign Affairs (MoFA). For priority products, the commercial attachés would need to collect from EDB/MoFA all the required promotional materials (i.e.: IoI) (movies, brochures, technical information and success stories to enable the provision of this information to potential buyers and investors in Germany. The commercial attaché should be briefed at least once a year by EDB/BOI/MoFA about the technical aspects of the products to be promoted...."

- $\quad$ INT 14 - ITC

INT 15 and INT 16 are members of the Sri Lanka Electronic Manufacturers and Exporters Association (SLEMEA). They mentioned that their role entailed promoting sectors and building relationships by recognizing the importance of government-to-government relationships, broader engagements at the ministerial level and the nurturing of existing relationships for international business outcomes. 


\subsection{Findings for the Research Question (RQ) 2: What Are the Most Successful International Trade Promotional Activities Organized by the Sri Lankan Foreign Mission in Germany?}

The study identifies the perceptions of different stakeholders on the trade promotion activities carried out by the foreign missions.

INT 1 stated that it is important to organize business forums with buyers and potential investors. He further stated that seminars should also be organized. He mentioned that emailing flyers and product catalogues to potential buyers or investors is not a practical and accurate method since usually buyers would not open these emails and they will most probably stay in the spam of their mailboxes.

INT 3 and INT 4 both stated that it was important to participate in trade fairs. They further mentioned that for greater effectiveness, business-to-business sessions should be carried out.

INT 6 mentioned that there have not been any trade promotion activities organized by the foreign missions in the EEC sector. However, other embassies such as Brazil had organized several trade fair participation activities. He further stated that the foreign missions had also arranged business-to-business sessions when a delegation visited a host country. But this has not happened in Germany. Moreover, he stated that EEC companies would be participating in one of the largest trade fairs which sources technology - Productronica in mid-November 2019.

INT 7 stated that they reached Germany through their connections with Switzerland. He stated that there is lack of support from Sri Lanka. He further stated that there are several aspects to consider when approaching German buyers.

INT 8 stated that the lack of German delegations visiting Sri Lanka hindered trade as far as he knew. This interviewee further mentioned that it is understood that the trade delegations which go to Germany do not include many importers.

INT 11 mentioned that they had already carried out a market study in Germany and due to the Generalized System of Preferences (GSP) plus facility we had identified, industrial automobile sector, telecommunication sector, consumer electronics sector, industrial automation sector and the IoT sector are the most potential sectors in this category in Germany. However, since this is the first time EDB was participating in an EEC related trade fair he is unaware of other trade promotion activities and the required support is not efficiently extended by the foreign mission.

INT 12 and INT 13 mentioned that inward and outward delegations are organized with the support of the foreign mission. They further stated that sufficient support was not extended by the foreign mission to participate in the trade fairs and business-to-business meetings. They also mentioned the importance of country branding.

INT 14 stated that the Commercial Attaché at the Mission should identify potential companies to meet in Germany in order to promote SL exports, services or investments. He further mentioned that the mission could also organize special events to invite German companies to promote SL products.

A few interviewees such as INT 15 and INT 16 mentioned that their companies had not penetrated the German market but they see potential in the German market and that they were unaware of the trade promotion activities carried out.

\subsection{Findings for the Research Question (RQ) 3: What Are the Most Effective Trade Promotion Activities which should Be Carried out by Foreign Missions?}

This section identifies the most effective trade promotion activity according to the stakeholders, through the exposure, reach and business they have achieved.

INT 1 stated that the best tool was to participate in trade fairs to gain more exposure both for the country and the sector. He further stated that the capability of the sector should be shown while participating in these trade fairs.

INT 4 stated that it was important to participate in trade fairs continuously and display the presence of the country and the company. This interviewee also stated that continuous participation in trade fairs will increase buyer confidence through visual and verbal communication.

INT 6 mentioned that the most effective activities are trade fair participation and business-to-business (B2B) meetings.

INT 7 also stated that trade fair participation followed by B2B meetings will improve the trade relations and generate more leads. It will further establish business linkages and export orders. This particular interviewee suggested the following activities as effective methods: participating in trade exhibitions, participating in trade conferences and advertising in relevant magazines. 

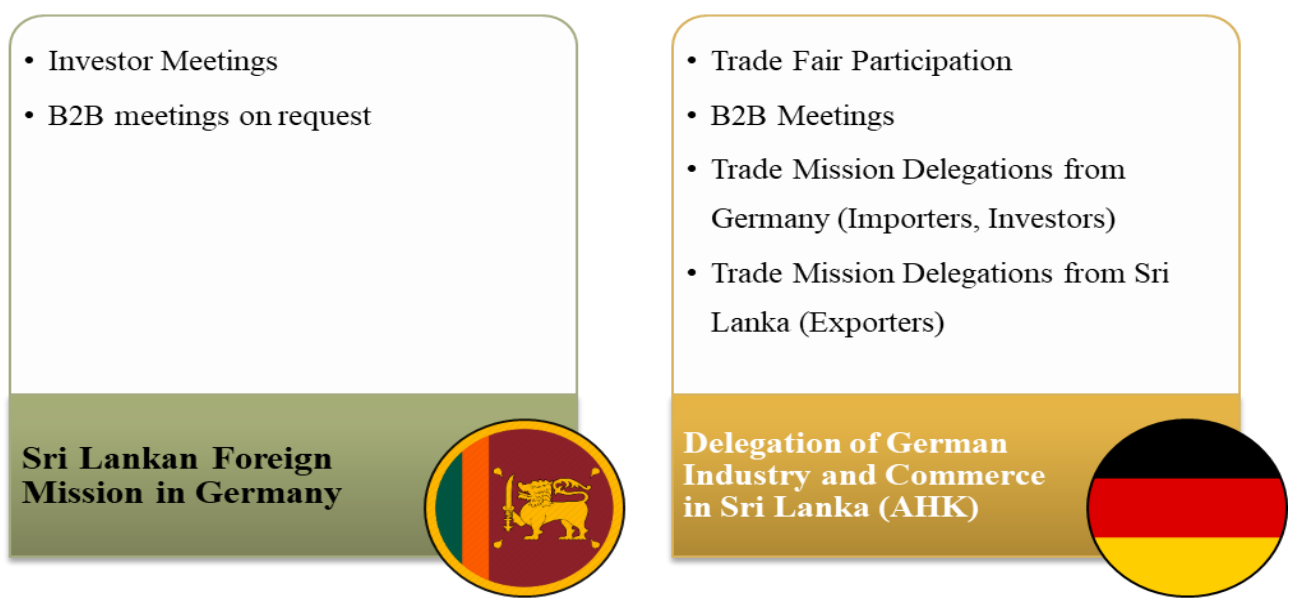

Figure 6. Summary of activities carried out by the trade related foreign missions in Sri Lanka and Germany

\section{Discussion}

The unique strength of trade fairs compared to any other form of business-making depends on a combination of three main elements, namely, personal contact, information and deal-making, according to the study. On the basis of the international research literature and the Sri Lankan Government Acts such as Diplomatic Privileges Act (No. 9 of 1996) (DPL Act | Ministry of Foreign Affairs Sri Lanka, 2017), the conceptual model was formulated and the interviews were carried out to understand the stakeholders' perspectives on the research questions. The following diagram depicts the findings which have been also grouped according to the broad themes identified in the literature review.

As in the case of the conceptual model some activities were repeated under the thematic areas identified in the literature review.

Among the activities, the international perspective on pre-fair workshops to groom the participants of the trade fairs and the service-capability map were identified as crucial components by the interviewees of this study.

According to the interviewees, the role of the foreign missions can be varied. The majority of the activities were conformed to the literature review findings. Table 4 below shows the actual role and the expected role of the foreign mission along with the new activities which were not identified in the model.

Table 4. Summarization of Role of Foreign Missions - Stakeholder Perspective

\begin{tabular}{|c|c|}
\hline Tasks & Objectives \\
\hline $\begin{array}{l}\text { Activities carried out by the } \\
\text { foreign mission }\end{array}$ & $\begin{array}{ll}\text { 1. } & \text { Coordination } \\
\text { 2. } & \text { Identifying potential sectors } \\
\text { 3. } & \text { Logistics } \\
\text { 4. } & \text { Country Image Building } \\
\text { 5. } & \text { Trade Promotion through trade fairs, B2B meetings } \\
\text { 6. } & \text { Tourism Promotion } \\
\text { 7. } & \text { Trade Information (markets, buyers, products) } \\
\text { 8. } & \text { Gathering and dissemination of market information } \\
\text { 9. Networking } \\
\text { 10. Arranging B2B meetings on request } \\
\text { 11. Problem solving and assistance with trade disputes }\end{array}$ \\
\hline Stakeholder expectations & $\begin{array}{l}\text { 1. Development and introduction of Government relations } \\
\text { 2. Partner search and negotiations } \\
\text { 3. Market development programs } \\
\text { 4. Export service programs (counseling and advice) } \\
\text { 5. Referral }\end{array}$ \\
\hline $\begin{array}{l}\text { Proposed new activities to bridge } \\
\text { the gap }\end{array}$ & $\begin{array}{l}\text { 1. Mapping Sri Lanka's product/service capability into the value chain } \\
\text { 2. Pre-fair workshops }\end{array}$ \\
\hline
\end{tabular}

There are many aspects of trade fairs such as generating leads and facilitating engagement and interaction which can be carried out by strong leadership and strategic relationships of the foreign missions, according to the 
findings. Additionally, according to this study, the presence that embodies both the occupancy and the charisma of the head of the foreign missions has a strong bearing when they get involved in trade fairs.

Further, the following facts have to be considered when carrying out trade promotions.

1. Ability to meet quality expectation and maintain quality,

2. Ability to keep cost competitive and maintain competitiveness in the long run,

3. Stable policies for trade, and

4. Details of quality infrastructure in Sri Lanka.

\section{Limitations}

This study is a qualitative study with an opportunity to prove the findings through a quantitative study. However, due to certain limitations this could not be achieved. Hence future researchers can focus on the same aspects in from a quantitative approach.

Two (2) respondents were eliminated due to data saturation and the political change which happened due to the Presidential Elections. Hence, with 14 respondents, only 12 interviews were completed. The political change of Sri Lanka during the data collection period resulted in missing the chance to interview some key figures in the industry such as the Chairperson and Chief Executive of the Export Development Board.

The third limitation of this study was that it was done using the convenient sampling method. Due to e time constraints, the quality of respondents might vary and there can be issues which prevent using many respondents. The snowball sampling technique was used to reach respondents or through information from the specifically identified group of people in the industry. However, it is suggested that future researchers should prepare a proper sampling structure before commencing their work.

The time limitation of three (3) months to complete the study is the fourth limitation. It only allowed to look at the issues in general terms with a high-level overview. The study could be extended to identifying the exact strategies and actions to be carried out prior to the trade fair, during the trade fair and after the trade fair. This provides an opening to future researchers on the same subject.

The fifth limitation is the manual data analysis method. The analysis could be done in a methodical manner using a qualitative data analysis computer software package such as Nvivo, which is used for the analysis of unstructured text, audio, video, and image data, including (but not limited to) interviews, focus groups, surveys, social media, and journal articles.

Resource limitation was the sixth limitation since access to foreign counterparts was restricted. Hence, the study had to be limited to the known Sri Lankan resources. This study should be extended to many sectors and multiple countries.

\section{Future Research}

Based on the afore-mentioned limitations, the following areas can be identified as future research opportunities. Some of these areas were identified in this study and some need further analysis using mixed-method researches.

Future researchers could examine the relationship between trade promotion and leadership of a foreign mission; understand the communication gaps of foreign missions with home country counter-parts; the role of leadership of a foreign mission in promoting international trade; the role of Government Officials in promoting international trade; effect of business-to-business training given to Sri Lankan exporters in promoting international trade; effectiveness of trade fairs in promoting Sri Lankan international trade; urgency for a trade policy change to boost Sri Lankan trade; does the New Trade Policy boost international trade?; how effective is the role of EDB in Sri Lankan international trade?; effect of trade fairs in promoting international trade and the mediating role of leadership and communication; strategies for carrying out successful trade fair participation; and the impact of the relationship between the host country Government on effective trade promotion.

\section{Conclusion}

There are many trade promotion activities carried out by different stakeholders in trade, namely, government institutions and commercial attaches. However, it is discerned that there is no coordinated effort to promote trade in Sri Lanka as a nation. It is evident that all institutions work in silos and duplicate almost all the activities. Due to the lack of coordination, exporters and importers do not get the real benefit out of these trade promotion activities.

Hence the study was carried out by selecting Germany, Sri Lanka's fourth largest export destination and 
selecting EEC which is a NES focus sector. In this study, the following main objectives were supported by the research questions. With specific reference to Sri Lankan Embassy in Germany for EEC sector, the following 2 objectives were acknowledged by the researcher. The first objective is to explore the role of the foreign mission in promoting exports in the host market and the next is to identify the effective international trade promotional activities organized by the foreign mission in the host market.

Qualitative methodology was selected along with convenient and snowball sampling for the study. Data was collected via three main sources: semi-structured interviews, focus groups and secondary sources. Interviews were Face-to-face, Skype, Video Conferencing, Phone calls, focus groups, and email.

The key findings of the analysis confirm that the role of a foreign mission include internalizing industries, promoting, business intelligence, stakeholder communication, building strategic relationships and inter-governmental engagement, respectively and also a model was developed to represent the role of a foreign mission in promoting international trade. Further, this research identified the importance of trade fair participation and business-to-business meetings to promote trade in the host country.

Internet, e-mail, Skype and video conferences made it possible to communicate and exchange information effectively in real time. However, they are limited to the possibility of physical testing of products and the lack of personal interaction. Physical presence, especially in intercultural communication, is very important and can make a difference. In addition, immediate feedback and communication adaptation are key. Hence, personal contacts and strategic relationships between parties are crucial for trade.

Trade fairs draw together sellers and buyers and, in most instances, provide the highest concentration of these decision-makers. In fact, they provide an opportunity to reach specific individuals who would otherwise be difficult to contact. The benefit of trade fairs is that visitors are open to new information because that is the whole intention of visiting a fair. Hence, access to information is a vital factor.

Business deals are carried out by individuals in real life. Nonetheless, in order to make an arrangement, the parties involved need to build trust and establish confidence. Trade fairs are the ideal environment for meeting each other and building trust through complementing both parties. A successful business meeting at a trade fair can be the starting point for a long-term business relationship.

In addition, officers who have not yet gained international business expertise may face new and challenging circumstances, attitudes and/or procedures. Therefore, officers should familiarize themselves with the environment of the host country, its traditions and practices, its vocabulary as well as its verbal and non-verbal contact norms. European conduct can be different from the norms of another country, especially when it comes to trade. Many European business partners demand high quality standards and effective, dedicated and correct contact.

In order to ensure confident and trustworthy relationships with stakeholders to strengthen trade ties, specifically in the host market, the most effective approach is to meet them in person at trade fairs and follow up the contacts through business-to-business meetings.

Many future research opportunities lie within the ambit of this study. Understanding the limitations mentioned before such as time and resource restrictions, structured sampling should be used in future researches thus eliminating the aforementioned limitations.

Foreign missions spend a major part of their time on advisory roles and creating strategic relationships. However, this study recommends that trade promotion be reconfirmed as the core business in order to ensure that they are knowledgeable enough to participate in and facilitate visitors at trade fairs. Moreover, their role should entail arranging, coordinating and facilitating business linkage creation through business-to-business meetings as one of the major activities. These should be carried out to ensure efficient and successful trade promotion by virtue of foreign missions.

\section{References}

Aberdeen, T., \& Yin, R. K. (2009). Case study research: Design and methods (4th Ed.). Thousand Oaks, CA: Sage. The Canadian Journal of Action Research, 14(1), 69-71. https://doi.org/10.33524/cjar.v14i1.73

Bagir, Y. (2017). Impact of the Presence of Foreign Missions on Trade: Evidence from Turkey - Munich Personal RePEc Archive. Uni-Muenchen.De. Retrieved from https://doi.org/https://mpra.ub.uni-muenchen.de/80845/1/MPRA_paper_80845.pdf

Broek, S. (2019). Explaining trade missions: the role of program characteristics in explaining trade mission's outcomes. In Semantic Scholar. Retrieved August 14, 2019, from 
https://pdfs.semanticscholar.org/bb8b/92741e4b84104912d38f5b5f7d9e29fb1222.pdf

Diplomatic Bluebook. (2018). Ministry of Foreign Affairs of Japan. Retrieved from https://www.mofa.go.jp/policy/other/bluebook/2018/html/chapter3/c030300.html

DPL Act $\mid$ Ministry of Foreign Affairs Sri Lanka. (2017). mfa.gov.lk. Retrieved from https://www.mfa.gov.lk/dpl-act/

Electrical and Electronic components. (2018). www.srilankabusiness.com; Sri Lanka Export Development Board. Retrieved https://www.srilankabusiness.com/national-export-strategy/nes-electrical-and-electronic-components.html

European Commission. (2019). COMMISSION STAFF WORKING DOCUMENT - Country Report Germany 2019 Including an In-Depth Review on the prevention and correction of macroeconomic imbalances. European Commission. Retrieved from https://ec.europa.eu/info/sites/info/files/file_import/2019-european-semester-country-report-germany_en.pd $\mathrm{f}$

Germany | Ministry of Foreign Affairs Sri Lanka. (2017). mfa.gov.lk. Retrieved from https://www.mfa.gov.lk/missions/sri-lanka-missions-overseas/europe/germany-2/

ITC Export Potential Map. (2019). Intracen.Org. Retrieved from https://exportpotential.intracen.org/en/\#/markets/gap-chart?fromMarker=i\&exporter=144\&whatMarker=ls \&what $=14 \&$ toMarker $=\mathrm{j}$

Kostecki, M., \& Naray, O. (2007). DISCUSSION PAPERS IN DIPLOMACY Commercial Diplomacy and International Business. (Kostecki \& Naray, n.d.). Retrieved from https://www.clingendael.org/sites/default/files/pdfs/20070400_cdsp_diplomacy_kostecki_naray.pdf

Kotabe, M., \& Czinkota, M. (1992). State Government Promotion of Manufacturing Exports: A Gap Analysis. Journal of International Business Studies, 23, 637-658. Retrieved from https://doi.org/10.1057/palgrave.jibs.8490281

Lederman, D., Olarreaga, M., \& Payton, L. (2006, November 1). Export promotion agencies: what works and what doesn't. Documents. Worldbank.Org. https://doi.org/10.1596/1813-9450-4044

Lee, D. (2004). The Growing Influence of Business in U.K. Diplomacy. International Studies Perspectives, 5(1), 50-54. https://doi.org/10.1111/j.1528-3577.2004.00154.x

Mercier, A. (2007). Discussion Papers in Diplomacy Commercial Diplomacy in Advanced Industrial States: Canada, the UK, and the US. The Netherlands Institute of International Relations Clingendael, 108, 1-49. Retrieved from https://www.clingendael.org/sites/default/files/pdfs/20070900_cdsp_diplomacy_mercier.pdf

Ministry of Foreign Affairs Sri Lanka. (2019). Annual Performance Report 2018 - Ministry of Foreign Affairs Sri Lanka. In The Parliament of Sri Lanka (pp. 06-07, 103-113, 125-126). Retrieved from https://www.parliament.lk/uploads/documents/paperspresented/performance-report-ministry-of-foreign-affa irs-2018.pdf

Ministry of Foreign Affairs, \& Bandaranaike International Diplomatic Training Institute. (2019). SRI LANKA FOREIGN POLICY AND ECONOMIC DIPLOMACY DIALOGUE 2018 SUMMARY. In Lakshman Kadirgamar Institute of International Relations and Strategic Studies (Ed.), LAKSHMAN KADIRGAMAR INSTITUTE (pp. 20-31). Retrieved from https://lki.lk/wp-content/uploads/2019/10/SRI-LANKA-FOREIGN-POLICY-AND-ECONOMIC-DIPLOM ACY-DIALOGUE-2018-Summary.pdf (Original work published 2019)

Naray, O. (2008). Commercial Diplomacy: A Conceptual Overview. 7th World Conference of TPOs, The Hague, The Netherlands. Retrieved from http://www.intracen.org/uploadedFiles/intracenorg/Content/Trade_Support_Institutions/TPO_Network/Cont ent/Conferences/2008/NarayConferencepaper.pdf

Naray, O. (2015). An empirical analysis of the roles, activities and performance of commercial diplomats in promoting international business. Rero.Ch. Retrieved from https://doc.rero.ch/record/256724

OEC World- Germany (DEU) Exports, Imports, and Trade Partners. (2017). OEC.World. Retrieved from https://oec.world/en/profile/country/deu/ 
Okano-Heijmans, M. (2011). Conceptualizing Economic Diplomacy: The Crossroads of International Relations, Economics, IPE and Diplomatic Studies. The Hague Journal of Diplomacy, 6(1-2), 7-36. https://doi.org/https://doi.org/10.1163/187119111X566742

Palangkaraya, A., \& Webster, E. (2019). Entering the Export Markets: Do Trade Missions Help? In Economic Research Institute for ASEAN and East Asia (ERIA). Retrieved from https://www.eria.org/uploads/media/ERIA-DP-2018-15.pdf

Potter, E. (2004). Branding Canada: The Renaissance of Canada's Commercial Diplomacy. International Studies Perspectives, 5(1), 55-60. https://doi.org/10.1111/j.1528-3577.2004.00155.x

Rose, A. (2005). The Foreign Service and Foreign Trade: Embassies as Export Promotion. World Economy, 30. https://doi.org/10.1111/j.1467-9701.2007.00870.x

Ruël, H., Zuidema, L., \& 123, N. (2012). The Effectiveness of Commercial Diplomacy A Survey Among Dutch Embassies and Consulates. Retrieved from https://www.clingendael.org/sites/default/files/pdfs/20120504_cling_research_artikel_discussionpaperindipl omacy_123_ruel_and_zuidema.pdf

Saner, R., \& Yiu, L. (2003). Discussion Papers in Diplomacy International Economic Diplomacy: Mutations in Post-modern Times. Academia.Edu. Retrieved from https://www.academia.edu/23190973/Discussion_Papers_in_Diplomacy_International_Economic_Diploma cy_Mutations_in_Post-modern_Times

Sorenson, V., \& Curzon, G. (1966). Multilateral Commercial Diplomacy: The General Agreement on Tariffs and Trade and Its Impact on National Commercial Policies and Techniques. Journal of Farm Economics, 48(1), 141. https://doi.org/10.2307/1236193

\section{Copyrights}

Copyright for this article is retained by the author(s), with first publication rights granted to the journal.

This is an open-access article distributed under the terms and conditions of the Creative Commons Attribution license (http://creativecommons.org/licenses/by/4.0/). 